\title{
Oral Congenital Melanocytic Nevus: A Rare Case Report and Review of the Literature
}

\author{
Helvécio Marangon Júnior ${ }^{1}$ Paulo Eduardo Alencar Souza ${ }^{1}$ • \\ Rodrigo Villamarim Soares ${ }^{2} \cdot$ Bruno Augusto Benevenuto de Andrade $^{3}$. \\ Oslei Paes de Almeida ${ }^{4}$ Martinho Campolina Rebello Horta ${ }^{1}$ (D)
}

Received: 25 March 2015/Accepted: 29 June 2015/Published online: 5 July 2015

(C) Springer Science+Business Media New York 2015

\begin{abstract}
Melanocytic nevi are congenital or acquired benign proliferations of cells of melanocytic origin. Oral congenital melanocytic nevi are rare, and only a few cases have been reported in the literature. The purpose of this study is to present the clinical, histological and immunohistochemical features of an oral congenital melanocytic nevus in a 16-year-old female with an 11-year follow-up and to review the pertinent literature. The reported case is the fifth well-documented case report of oral congenital melanocytic nevus in the English literature and the first with a long period of follow-up, thereby making it an important contribution to the knowledge regarding this uncommon oral mucosa lesion.
\end{abstract}

Keywords Oral mucosa $\cdot$ Congenital melanocytic nevus · Histopathology $\cdot$ Immunohistochemistry

Martinho Campolina Rebello Horta

martinhohorta@pucminas.br

1 Oral Pathology Division, School of Dentistry, Pontifical Catholic University of Minas Gerais (PUC Minas), Av. Dom José Gaspar 500, Prédio 46, Sala 110, Belo Horizonte, MG CEP: 30535-901, Brazil

2 Periodontology Division, School of Dentistry, Pontifical Catholic University of Minas Gerais (PUC Minas), Belo Horizonte, MG, Brazil

3 Oral Pathology Division, Department of Oral Diagnosis and Pathology, School of Dentistry, Federal University of Rio de Janeiro (UFRJ), Rio de Janeiro, RJ, Brazil

4 Oral Diagnosis Department, Piracicaba Dental School, University of Campinas (UNICAMP), Piracicaba, SP, Brazil

\section{Introduction}

Melanocytic nevi are congenital or acquired benign proliferations of cells of melanocytic origin derived from neural crest [1]. These lesions are typically found on the skin, and they are uncommon in the oral mucosa [2-4]. An estimated annual incidence of 4.35 cases per 10 million individuals has been previously described for excised oral melanocytic nevi (OMN) [4]. OMN are observed mainly in the hard palate and buccal mucosa, affecting women more frequently with an average age of 35 years [3].

The term congenital melanocytic nevus (CMN) should be applied to benign melanocytic proliferations present at birth as well as to lesions that, although not apparent at birth, show typical clinical and histological features of CMN [5]. Oral CMN is rare, and to date, only four welldocumented cases have been reported in the English literature [6-9].

Here, we report a case of an oral CMN in a 16-year-old female patient; we discuss its clinical, histopathological, and immunohistochemical features and we review the pertinent literature.

\section{Case Report}

A 16-year-old female white patient complaining of "a growth in the cheek" was referred to the Oral Pathology Clinic at Pontifical Catholic University of Minas Gerais (PUC Minas). She reported that she had the lesion since childhood and that a slow and continuous growth occurred. The medical history of the patient was not contributory.

An extra-oral clinical examination showed no alterations. An intra-oral clinical examination showed a large diffuse swelling on the left buccal mucosa, extending to the 
retromolar triangle and lower posterior alveolar mucosa. The lesion showed ill-defined borders, was approximately $5 \times 4 \mathrm{~cm}$ in size, and was formed by numerous diffuse papules (each measuring 1-4 $\mathrm{mm}$ in diameter). Some papules were similar in color to the normal mucosa, and others displayed various scattered pigmented areas, ranging from brown to black (Fig. 1a). No involvement of the ipsilateral mucosa of the floor of the mouth or tongue was observed. There is also no change in color of the overlying skin. Moreover, mandibular bone alterations in the area of the lesion were not identified in periapical radiographs.

A clinical diagnosis of melanocytic nevus or malignant melanoma was proposed. An incisional biopsy was performed, and H\&E-stained histological sections showed an oral mucosa lined by parakeratinized squamous epithelium with hyperplasia and a dense diffuse infiltrate of small monomorphous melanocytes (nevus cells) in the lamina propria (Fig. 2a, b). The nevus cells were arranged in a band-like pattern (Fig. 2a, b), streaming through collagen bundles and occasionally presenting melanin, but without cellular atypia or mitosis (Fig. 2c-f). The mucosa
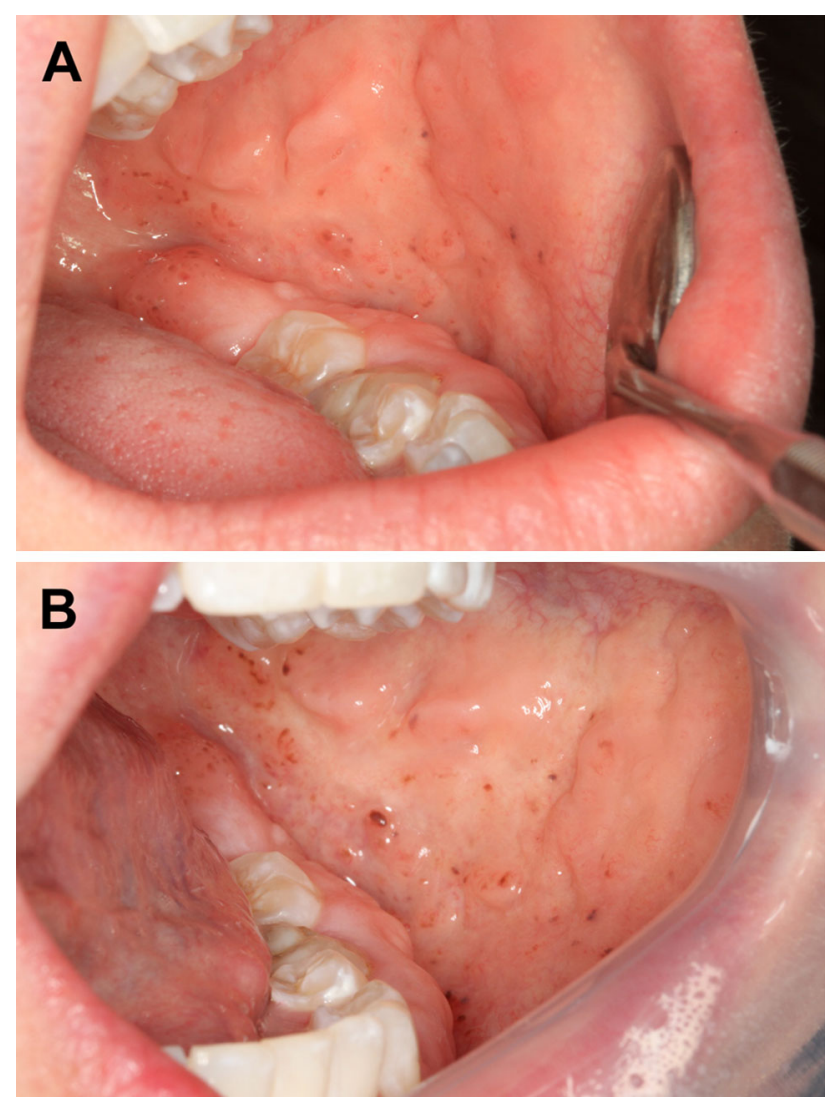

Fig. 1 Intra-oral view of the lesion. a Located on the left buccal mucosa, retromolar triangle and lower posterior alveolar mucosa, the lesion was formed by numerous diffuse papules displaying various scattered pigmented areas. b After an 11-year follow-up, regardless of a slight increase in the number of pigmented areas, no significant clinical changes were observed epithelium showed no melanin in basal cells or melanocytic hyperplasia (Fig. 2c, d). Based on the clinical and histopathological features, the diagnosis of oral CMN was established.

To better characterize the case, immunohistochemistry for HMB-45, fatty acid synthase (FASN), S-100, bcl-2, and $\mathrm{Ki}-67$ was performed. The melanocytic cells were negative for HMB-45 (Fig. 3a) and positive for FASN, S-100 and bcl-2 (Fig. 3c-e). Finally, the positivity of the melanocytic cells for Ki-67 was $<1 \%$ (Fig. 3f).

The patient has been under close follow-up for the last 11 years. Despite a slight increase in the number of pigmented areas in the lesion during these years, there were no significant changes in its clinical features (Fig. 1b).

\section{Discussion}

The oral mucosa is an uncommon site for the presentation of a melanocytic nevus [2-4]. As its cutaneous counterpart, OMN can be congenital or acquired. Nevertheless, congenital OMN is a very rare lesion [9]. To the best of our knowledge, this is the fifth well-documented case report of oral CMN in the English literature (Table 1). Similar to the present case, all previously reported cases occurred in young female patients, and they were located on the gingiva of a 3-year-old [6], labial mucosa of a 7-year-old [7], buccal mucosa of a 19-year-old [8], and palatal mucosa of a 19-year-old patient [9].

Cutaneous CMN appears as a flat café au lait spot at birth, and during the first years of life, it can appear as dark brown macules, papules or plaques, which can display a heterogeneous pattern. Some degree of hypo pigmentation within the lesion, the occurrence of verrucous changes and hypertrichosis, as well as satellite lesions, have also been described $[1,10]$. CMN is traditionally divided according to size into small (up to $1.5 \mathrm{~cm}$ ), medium $(1.5-19.9 \mathrm{~cm}$ ), and large or giant (20 $\mathrm{cm}$ or more) [10]. Although the incidence of $\mathrm{CMN}$ in the general population is elevated at 1:100 live births, when only giant nevi are considered, this number is drastically reduced to $1: 20,000$ [11].

In the four cases of oral $\mathrm{CMN}$ previously reported (Table 1), the main clinical characteristics were well-demarcated plaques or papules showing homogenous or scattered pigmentation and small size, with all lesions displaying a diameter of no more than $1.5 \mathrm{~cm}$. Although the present case also displayed a papular surface and dispersed pigmented area, its ill-defined borders and larger size differs from the previous cases.

The differential diagnosis of OMN generally includes pigmented lesions of the mouth, such as melanotic macule, physiological pigmentation, smoker's melanosis, amalgam tattoo, and malignant melanoma [12]. In the present case, 

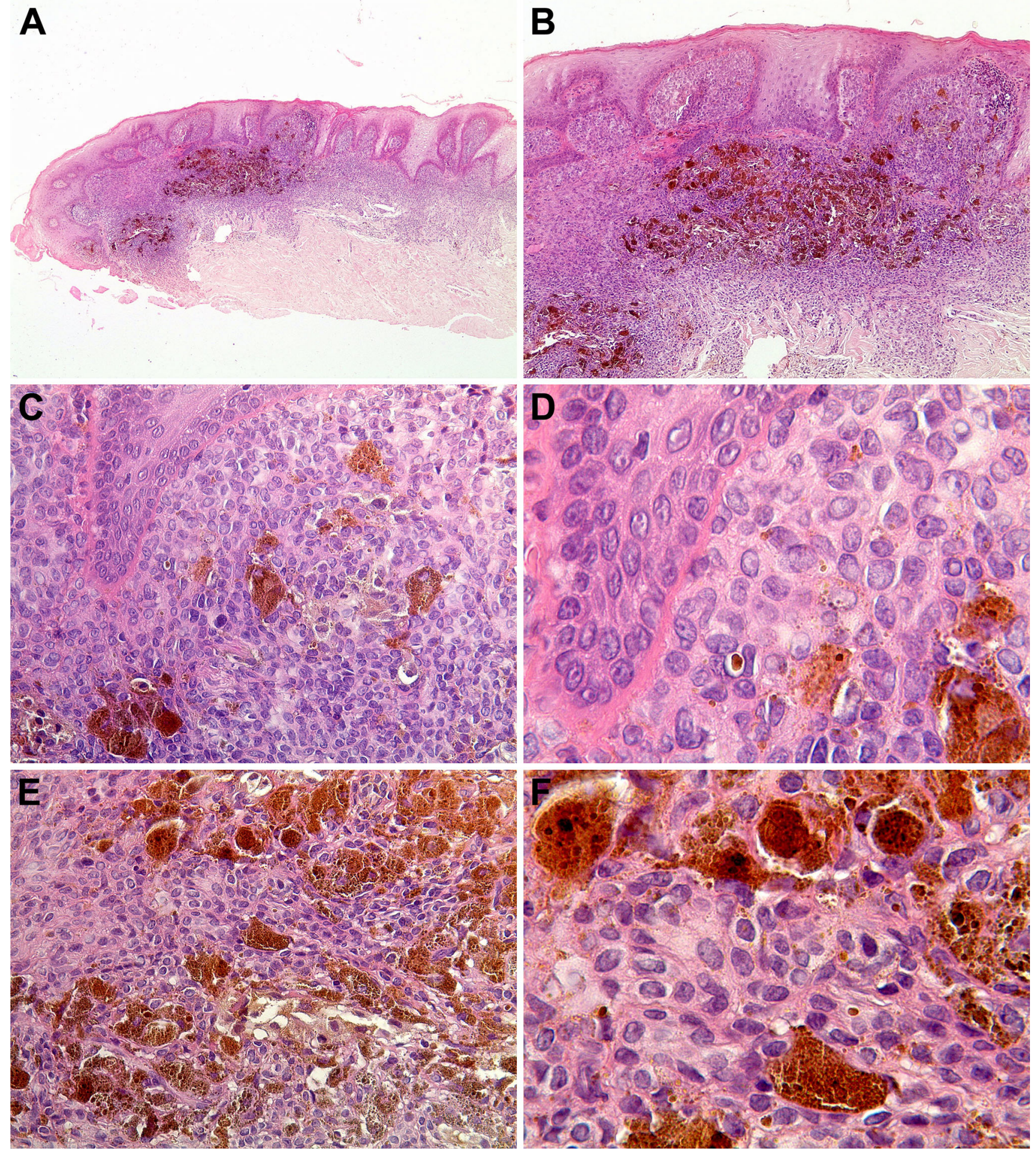

Fig. 2 Histopathological features of the lesion. Oral mucosa presenting a diffuse infiltrate of small monomorphous melanocytes arranged in a band-like pattern in the lamina propria, streaming through collagen bundles and showing melanin production. No

due to its size and heterogeneous pigmented surface, the differential diagnosis was restricted to melanocytic nevus and malignant melanoma.

melanin in basal cells or melanocytic hyperplasia was observed in the mucosa epithelium, a HE $\times 40$; b $\mathrm{HE} \times 100$; c $\mathrm{HE} \times 400$; d HE $\times 1000$; e HE $\times 400$; f HE $\times 1000$

CMN differs from acquired nevus because of its presence at birth, larger size, and histopathological features. Histopathologically, both types may be junctional, 

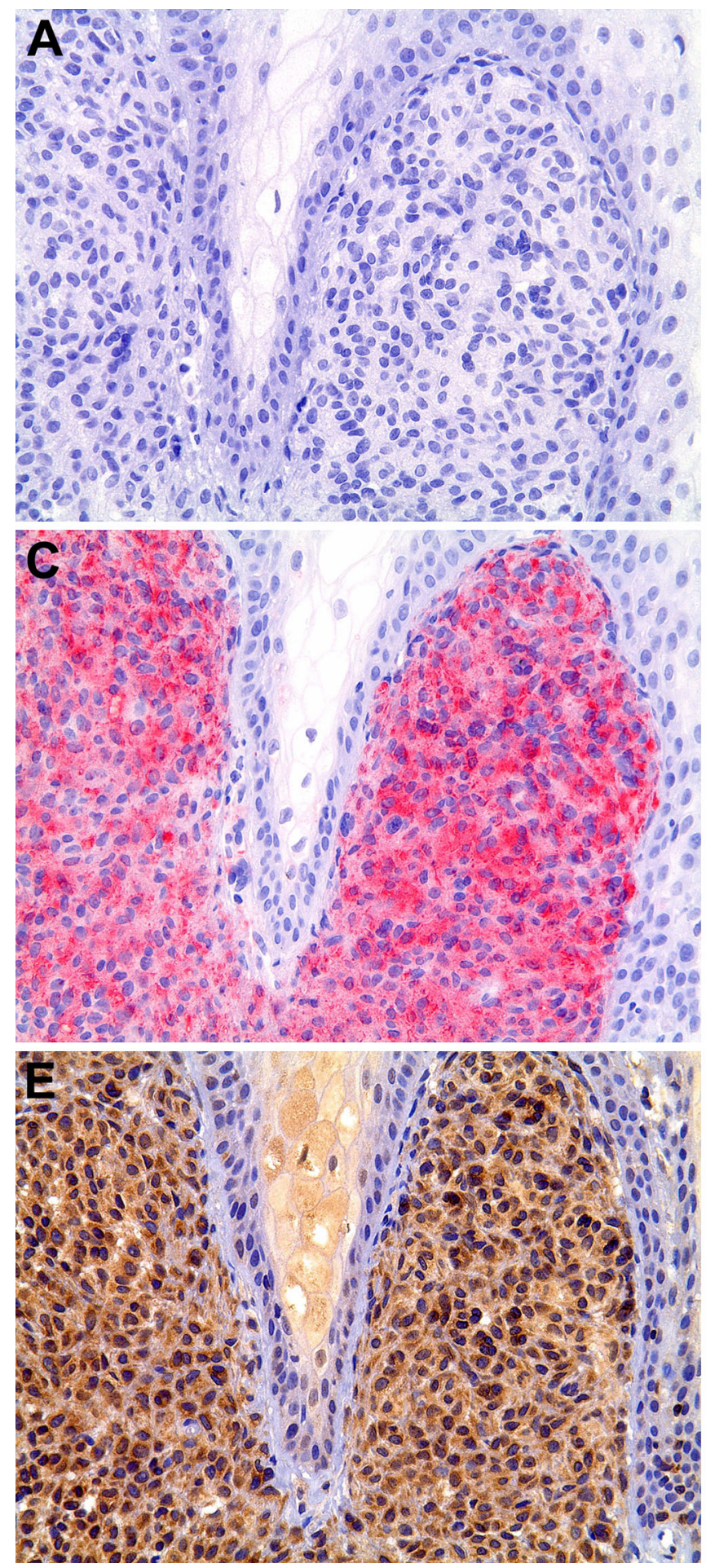

Fig. 3 Immunohistochemical features of the lesion. a Cells were negative for HMB-45 (Permanent Red $\times 400$ ). b Malignant melanoma samples employed as a positive control for HMB-45 (Permanent Red $\times 400$ ). c Cells were positive for FASN (Permanent Red $\times 400$ ). d Cells were positive for S-100 (Permanent Red $\times 400$ ). e Cells were

compound or intradermal (intra mucosal), but CMN generally shows a diffuse band-like infiltrate of melanocytes streaming through collagen bundles rather than the classic
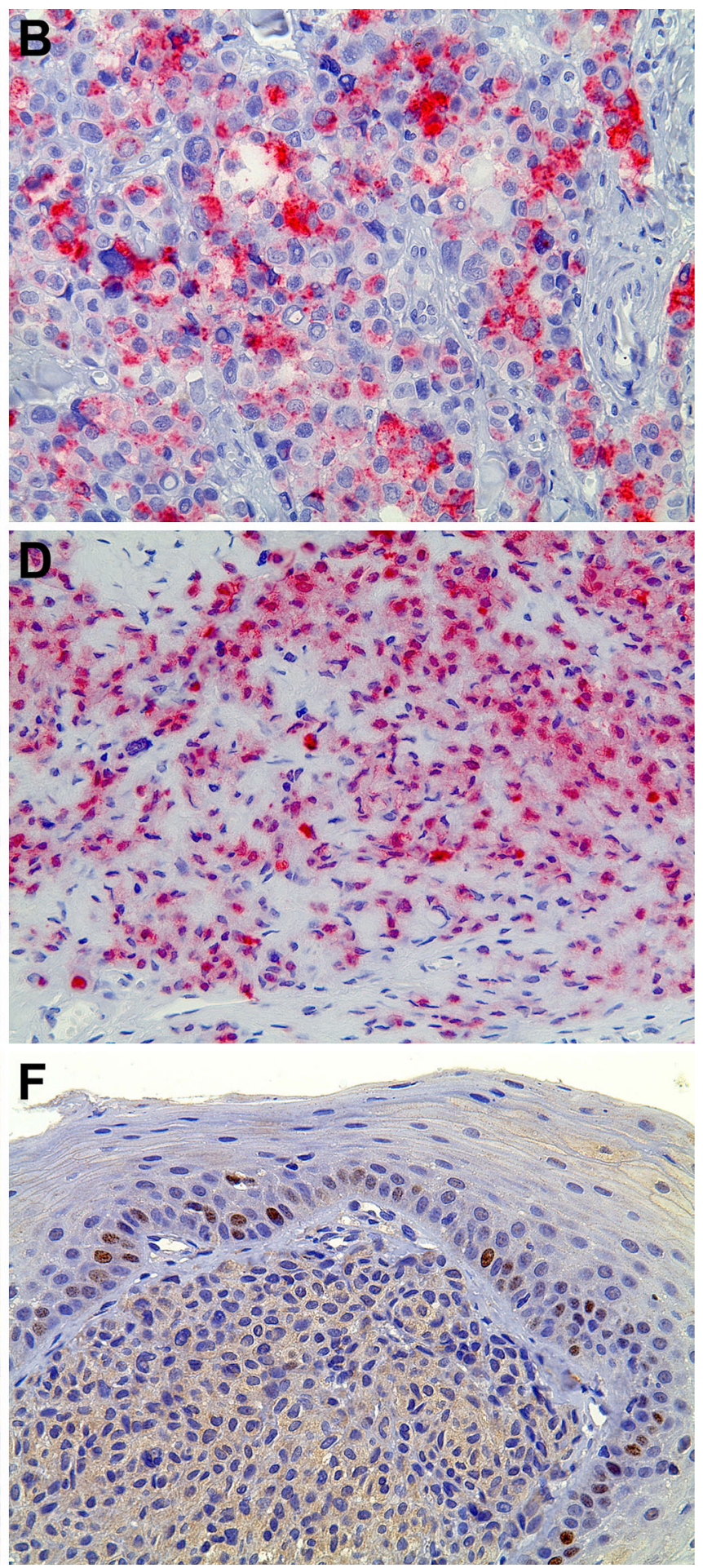

positive for bcl-2 (streptavidin-biotin-peroxidase $\times 400$ ). f The positivity of the melanocytic cells for Ki-67 was $<1 \%$ (streptavidinbiotin-peroxidase $\times 400$ ). Keratinocytes of the oral mucosa epithelium were used as an internal positive control

cell nest formation of acquired nevus [1, 5]. Although this suggestive histological feature was observed in the present case, the oral CMN reported by Takeda [7] showed the 
Table 1 Features the oral CMN previously reported in the English literature

\begin{tabular}{|c|c|c|c|c|c|c|}
\hline Authors & Age & Gender & Clinical features & Histopathology & Immunohistochemistry & Management/outcome \\
\hline $\begin{array}{l}\text { Allen and } \\
\text { Pellegrini } \\
{[6]}\end{array}$ & $\begin{array}{l}\text { 3- } \\
\text { year- } \\
\text { old }\end{array}$ & Female & $\begin{array}{l}\text { Dark brown plaque with } \\
\text { uniform margins; located } \\
\text { at the right posterior } \\
\text { mandibular lingual } \\
\text { gingiva; not noticed } \\
\text { previously; dimensions: } \\
0.8 \times 1.5 \mathrm{~cm}\end{array}$ & $\begin{array}{l}\text { Intramucosal sheets of } \\
\text { melanocytes just beneath } \\
\text { the oral mucosa } \\
\text { epithelium, extending to } \\
\text { the deep margin of the } \\
\text { sample; melanin } \\
\text { deposits; no cellular } \\
\text { atypia or mitosis }\end{array}$ & Not performed & $\begin{array}{l}\text { Excisional biopsy with no } \\
\text { recurrence after } \\
6 \text { months follow-up }\end{array}$ \\
\hline Takeda [7] & $\begin{array}{l}\text { 7- } \\
\text { year- } \\
\text { old }\end{array}$ & Female & $\begin{array}{l}\text { Brownish-black, well- } \\
\text { circumscribed tumor; } \\
\text { located at upper labial } \\
\text { mucosa; noticed since } \\
\text { birth; dimensions: } \\
0.65 \times 0.7 \mathrm{~cm}\end{array}$ & $\begin{array}{l}\text { Intramucosal nests of } \\
\text { ovoid-shaped nevus } \\
\text { cells, extending from } \\
\text { lamina propria to deep } \\
\text { submucosal connective } \\
\text { tissue; scattered } \\
\text { multinucleated giant } \\
\text { cells; no cellular atypia } \\
\text { or mitosis; hyperplasia } \\
\text { of the oral mucosa } \\
\text { epithelium }\end{array}$ & Not performed & $\begin{array}{l}\text { Excisional biopsy with no } \\
\text { recurrence after } 3 \text { years } \\
\text { follow-up }\end{array}$ \\
\hline $\begin{array}{l}\text { Rose et al. } \\
{[8]}\end{array}$ & $\begin{array}{l}\text { 19- } \\
\text { year- } \\
\text { old }\end{array}$ & Female & $\begin{array}{l}\text { Multiple and widespread } \\
\text { pigmented papules, } \\
\text { nodules and tumors; } \\
\text { located at lower back, } \\
\text { trunk, palms, soles, face } \\
\text { and buccal mucosa; } \\
\text { noticed since birth; } \\
\text { dimensions: } 20 \mathrm{~cm} \\
\text { (lower back) and } \\
0.5-5 \mathrm{~cm} \text { (other sites); } \\
\text { the specific features of } \\
\text { the oral mucosa lesion } \\
\text { were not specified }\end{array}$ & $\begin{array}{l}\text { Performed only in skin } \\
\text { lesion samples; } \\
\text { intradermal, round to } \\
\text { oval, monomorphous } \\
\text { melanocytes arranged in } \\
\text { nodular and plexiform } \\
\text { patterns; few scattered } \\
\text { spindle-shaped } \\
\text { melanocytes; melanin } \\
\text { deposits; splaying of } \\
\text { melanocytes between } \\
\text { collagen fibers }\end{array}$ & $\begin{array}{l}\text { Performed only in skin } \\
\text { lesion samples: } \\
\text { S-100 (positive) } \\
\text { HMB-45 (negative) }\end{array}$ & $\begin{array}{l}\text { Excision of } 3 \\
\text { representative skin } \\
\text { nodules for } \\
\text { histopathology and } \\
\text { immunohistochemistry; } \\
\text { no follow-up }\end{array}$ \\
\hline $\begin{array}{l}\text { Gilbert } \\
\text { et al. [9] }\end{array}$ & $\begin{array}{l}\text { 19- } \\
\text { year- } \\
\text { old }\end{array}$ & Female & $\begin{array}{l}\text { Well-demarcated circular } \\
\text { plaque, predominantly } \\
\text { erythematous with } \\
\text { scattered brown } \\
\text { pigmentation; located at } \\
\text { palatal mucosa; noticed } \\
\text { since } 3 \text { months of age; } \\
\text { dimensions: } \\
1.2 \times 1.1 \times 0.3 \mathrm{~cm}\end{array}$ & $\begin{array}{l}\text { Intramucosal sheets of } \\
\text { mature nevus cells } \\
\text { extending deep in the } \\
\text { lamina propria and } \\
\text { around salivary gland } \\
\text { ducts and nerves; } \\
\text { melanin deposits; } \\
\text { scattered multinucleated } \\
\text { giant cells; no cellular } \\
\text { atypia or mitosis; } \\
\text { papillomatous oral } \\
\text { mucosa epithelium }\end{array}$ & $\begin{array}{l}\text { melan A (positive) } \\
\text { HMB-45 (scanty- } \\
\text { positive) } \\
\text { Ki-67 (scanty- } \\
\text { positive) }\end{array}$ & $\begin{array}{l}\text { Incisional biopsy } \\
\text { followed by excisional } \\
\text { biopsy; no follow-up }\end{array}$ \\
\hline $\begin{array}{l}\text { Marangon } \\
\text { Junior } \\
\text { et al. } \\
\text { (current } \\
\text { case) }\end{array}$ & $\begin{array}{l}\text { 16- } \\
\text { year- } \\
\text { old }\end{array}$ & Female & $\begin{array}{l}\text { Diffuse swelling showing } \\
\text { papular surface, } \\
\text { scattered pigmented } \\
\text { areas and ill-defined } \\
\text { borders; located at the } \\
\text { left buccal mucosa } \\
\text { extending to alveolar } \\
\text { mucosa and retromolar } \\
\text { triangle; noticed since } \\
\text { childhood; dimensions: } \\
5 \times 4 \mathrm{~cm}\end{array}$ & $\begin{array}{l}\text { Dense diffuse } \\
\text { intramucosal infiltrate of } \\
\text { small monomorphous } \\
\text { melanocytes, arranged in } \\
\text { a band-like pattern; } \\
\text { splaying of melanocytes } \\
\text { between collagen fibers; } \\
\text { no cellular atypia or } \\
\text { mitosis; no melanin in } \\
\text { basal cells or } \\
\text { melanocytic hyperplasia; } \\
\text { hyperplasia of the oral } \\
\text { mucosa epithelium }\end{array}$ & $\begin{array}{l}\text { HMB-45 (negative) } \\
\text { FASN (positive) } \\
\text { S-100 (positive) } \\
\text { bcl-2 (positive) } \\
\text { Ki-67 }(<1 \%)\end{array}$ & $\begin{array}{l}\text { Incisional biopsy; no } \\
\text { surgical excision; no } \\
\text { significant changes after } \\
11 \text { years follow-up }\end{array}$ \\
\hline
\end{tabular}

The current case was also included 
classic nests of nevus cells (Table 1). Therefore, the histological aspects of CMN are variable, and pathognomonic characteristics do not occur in most of the cases [1, 10]. Small CMN is not easily diagnosed if not identified at birth because its clinical features can be similar to acquired nevus $[1,9]$. The present case was diagnosed as congenital due to its clinical and histological characteristics. The patient reported the presence of the lesion since childhood, although no information was provided about the lesion at birth. This does not eliminate the possibility that the lesion was apparent at birth because the identification of intraoral lesions is more difficult than cutaneous lesions in newborns. Furthermore, as mentioned above, it is important to emphasize that the diagnosis of CMN does not depend on its presence at birth but mainly on the presence of suggestive clinical and histological features [5]. In fact, of the four previously reported cases of oral CMN, two had been noticed since birth [7,8], one at 3 months of age [9] and one at 3 years [6] (Table 1).

The immunohistochemistry assays conducted in this study revealed that the lesion was negative for HMB-45, whereas a malignant melanoma sample used as a positive control showed positivity for this marker (Fig. 3b). HMB45 , although very useful for the diagnosis of melanoma, can also be positive in benign melanocytic lesions $[13,14]$. In fact, the oral CMN reported by Gilbert et al. [9] showed scanty-positivity for HMB-45. It is interesting that the present case was positive for FASN, a key enzyme in fatty acid synthesis responsible for converting acetyl-CoA to malonyl-CoA and long-chain fatty acids. Increased expression of this protein has been found in different malignancies, including malignant melanoma, due to the increased cellular energy demand of neoplastic cells [15]. Additionally, it was suggested that it can be useful for distinguishing between melanoma and nevus, as the latter is negative for FASN or expresses it weakly [16, 17]. Similar to the present case, Kapur et al. [15] observed high expression of FASN in CMN that was attributed to a fetal immunophenotype present in the melanocytes. The melanocytic cells in the present case were also positive for S-100, a recognized marker of melanocytic lesions [18]. Moreover, these cells were positive for bcl-2. Stefanaki et al. [19] investigated the expression of bcl-2 protein in $\mathrm{CMN}$ and found strong and diffuse cytoplasmic expression of this marker in all analyzed cases. Because the bcl-2 family of proteins is responsible for negative regulation of apoptosis and prolongation of cell survival, the authors suggested that the suppression of apoptosis could play an important role in the maintenance of nevus melanocytes. Finally, the positivity of the melanocytic cells for Ki-67 was $<1 \%$, indicating a low proliferative rate of the lesion. A similar result was previously observed in oral CMN [9]. Moreover, strong expression of this cell proliferation marker in oral melanomas and its very low expression in oral intramucosal nevi were recently reported, confirming that Ki-67 can be useful in the differential diagnosis of benign and malignant melanocytic lesions of the oral cavity [20].

The major reasons for treating $\mathrm{CMN}$ are the risk of malignant transformation and aesthetic motives. Surgical excision has been recommended as the first treatment choice. Although total excision of cutaneous lesions may result in high aesthetic satisfaction, its efficacy in reducing the incidence of malignant melanoma remains unproven [21]. Transformation of cutaneous CMN to melanoma appears to be related to its size, and the reported risk ranges from 1.1 to $45 \%$ [10].

There is no evidence of malignant transformation of OMN to melanoma, even in patients with multiple or congenital nevi [4]. In the present case the patient did not receive any treatment, the lesion was not surgically removed due its large size, and during the 11-year followup, no significant clinical changes were observed.

In summary, oral $\mathrm{CMN}$ is a rare lesion, and knowledge regarding its features is essential for its appropriate diagnosis and management by clinicians. The reported case contributes to the knowledge regarding oral CMN's clinical, histopathological, and immunohistochemical features, and it is the first with a long period of follow-up.

Acknowledgments Coordenação de Aperfeiçoamento de Pessoal de Nível Superior (Capes), Brazil; Conselho Nacional de Desenvolvimento Científico e Tecnológico (CNPq), Brazil; Fundação de Amparo à Pesquisa do Estado de Minas Gerais (FAPEMIG), Brazil.

Conflict of interest The authors declare that they have no conflict of interest.

\section{References}

1. Heffel DF, Thaller S. Congenital melanosis: an update. J Craniofac Surg. 2005;16:940-4.

2. Buchner A, Hansen LS. Pigmented nevi of the oral mucosa: a clinicopathologic study of 36 new cases and review of 155 cases from the literature. Part II: analysis of 191 cases. Oral Surg Oral Med Oral Pathol. 1987;63:676-82.

3. Buchner A, Leider AS, Merrell PW, Carpenter WM. Melanocytic nevi of the oral mucosa: a clinicopathologic study of 130 cases from northern California. J Oral Pathol Med. 1990;19:197-201.

4. Meleti M, Mooi WJ, Casparie MK, van der Waal I. Melanocytic nevi of the oral mucosa-no evidence of increased risk for oral malignant melanoma: an analysis of 119 cases. Oral Oncol. 2007;43:976-81.

5. Kerl H, Massi D, LeBoit PE, Bastian BC. Congenital melanocytic naevus. In: LeBoit PE, Burg G, Weedon D, Sarasin A, editors. World Health Organization classification of tumours. Pathology and genetics of skin tumours. Lyon: IARC Press; 2006. p. 93-4.

6. Allen CM, Pellegrini A. Probable congenital melanocytic nevus of the oral mucosa: case report. Pediatr Dermatol. 1995;12:145-8. 
7. Takeda Y. Congenital nevocellular nevus of the oral mucosa. Ann Dent. 1988;47:40-2.

8. Rose C, Kaddu S, El-Sherif TF, Kerl H. A distinctive type of widespread congenital melanocytic nevus with large nodules. J Am Acad Dermatol. 2003;49:732-5.

9. Gilbert ML, Hanna W, Ghazarian D, Dover D, Klieb HB. Congenital melanocytic nevus of the oral mucosa: report of a rare pigmented lesion and review of the literature. Clin Pract. 2011;1:28-9.

10. Alikhan A, Ibrahimi OA, Eisen DB. Congenital melanocytic nevi: where are we now? Part I. Clinical presentation, epidemiology, pathogenesis, histology, malignant transformation, and neurocutaneous melanosis. J Am Acad Dermatol. 2012;67:495-e1.

11. Castilla EE, Dutra MG, Oriolo-Parreiras IM. Epidemiology of congenital pigmented naevi: incidence rates relative frequencies. Br J Dermatol. 1981;104:307-15.

12. Meleti M, Vescovi P, Mooi WJ, van der Waal I. Pigmented lesions of the oral mucosa and perioral tissues: a flow-chart for the diagnosis and some recommendations for the management. Oral Surg Oral Med Oral Pathol Oral Radiol Endod. 2008;105:606-16.

13. Gown AM, Vogel AM, Hoak D, Gough F, McNutt MA. Monoclonal antibodies specific for melanocytic tumors distinguish subpopulations of melanocytes. Am J Pathol. 1986;123:195-203.
14. Evans MJ, Sanders DS, Grant JH, Blessing K. Expression of Melan-A in Spitz, pigmented spindle cell nevi, and congenital nevi: comparative immunohistochemical study. Pediatr Dev Pathol. 2000;3:36-9.

15. Kapur P, Rakheja D, Roy LC, Hoang MP. Fatty acid synthase expression in cutaneous melanocytic neoplasms. Mod Pathol. 2005;18:1107-12.

16. Innocenzi D, Alò PL, Balzani A, et al. Fatty acid synthase expression in melanoma. J Cutan Pathol. 2003;30:23-8.

17. de Andrade BA, León JE, Carlos R, et al. Expression of fatty acid synthase (FASN) in oral nevi and melanoma. Oral Dis. 2011;17:808-12.

18. Prieto VG, Shea CR. Immunohistochemistry of melanocytic proliferations. Arch Pathol Lab Med. 2011;135:853-9.

19. Stefanaki C, Antoniou C, Stefanaki K, et al. Bcl-2 and Bax in congenital naevi. Br J Dermatol. 2006;154:1175-9.

20. de Andrade BA, León JE, Carlos R, Delgado-Azañero W, Mosqueda-Taylor A, de Almeida OP. Expression of minichromosome maintenance 2, Ki-67, and geminin in oral nevi and melanoma. Ann Diagn Pathol. 2013;17:32-6.

21. Ibrahimi OA, Alikhan A, Eisen DB. Congenital melanocytic nevi: where are we now? Part II. Treatment options and approach to treatment. J Am Acad Dermatol. 2012;67:515-e1. 